\title{
IMPACTS OF NITROGEN AND PHOSPHORUS LOADS FROM VARIOUS SOURCES ON THE QUALITY OF SURFACE WATER BODIES IN THE CONTEXT OF CLIMATE CHANGE - CASE STUDY IN POLAND
}

\author{
HAMERLA, A. ${ }^{*}$ - KOŃCZAK, B. \\ Central Mining Institute Department of Water Protection, Plac Gwarków 1 40-166 Katowice, \\ Poland \\ (phone: $+48-32-259-2292)$ \\ *Corresponding author \\ e-mail: ahamerla@gig.eu; phone: +48-32-259-2292 \\ (Received $15^{\text {th }}$ Jul 2020; accepted $19^{\text {th }}$ Nov 2020)
}

\begin{abstract}
Climate change has the influence on the occurrence of phenomena such as extreme precipitation, flooding or prolonged rainless periods. The changes in precipitation characteristics have an impact on the nutrient cycle, especially in urban areas. The changes in water management on post mining areas could potentially deepen the problem. The aim of the study was to determine the influence of phosphorus and nitrogen loads from point and dispersed sources onto the water quality of analysed rivers in Poland. The proportion of nutrient loads discharged from different sources was calculated based on the available database, and the concentrations of nitrogen and phosphorus in river waters were analyzed by analytical methods. The results showed that the investment in the water treatment sector is not enough to achieve good status of surface water bodies. The dispersed sources influenced much more the quality of water rivers. The atmospheric deposition is a significant source of nitrogen and may be caused by the progressive changes in the climate. The extreme precipitation increase nitrogen flushed from agricultural systems and will pose greater risks to environmental stability of water. More sophisticated monitoring system of nutrients discharging form different sources may be an opportunity to reduce the pollution in rivers.
\end{abstract}

Keywords: water bodies, nutrients, mining areas, atmospheric deposition, agriculture

\section{Introduction}

The climate change is an indisputable phenomenon. Long-term observations of air temperature changes from 1850-1899 to 2001-2005 showed a global increase of $0.76^{\circ} \mathrm{C}$ (IPCC, 2007) with a tendency to further increase - the average of the 1850-1900 period and the 2003-2012 period is $0.78^{\circ} \mathrm{C}$ (IPCC, 2013). In addition, the high amplitudes of temperature changes related to the change in surface solar radiation are also observed (Qian et al., 2011), especially in the spring and winter time (Czernecki and Miętus, 2017). This causes the occurrence of extreme phenomena, such as extreme rainfall or on the other hand, extreme drought causing desertification. The global warming and the development of desertification phenomena have a major impact on the natural water cycle. As a result, there are changes in the amount of precipitation, groundwater level, and water levels in rivers and lakes (Malinowski and Skoczko, 2018). The studies of rainless periods were carried out in 1987-2008. Rainless periods in Poland ranged from 9-17 days, but in 2003 and 2008 it was observed that the total length of dry periods was even 101 and 100 days, respectively. The adverse directional changes in the sum of precipitation as well as the increase of the duration of rainless periods, can lead to a drop in the groundwater level. The seasonal variability of groundwater bodies status causes disruption of natural hydraulic continuity between groundwater and river waters 
(Tomalski, 2016). Statistically significant fluctuations in seasonal precipitation are reported in southern Poland. Polish rivers are very sensitive to the fluctuations of various climate-defining variables, with a greater effect being caused by periodic changes of precipitation than similar fluctuations caused by the change in air-temperature and the effectiveness of ground evaporation (Absalon and Matysik, 2016). The fluctuations in the precipitation contribute to the change of the amount of water outflow. The strongest and statistically significant changes in the outflow conditions are observed in the case of rivers drainage basins transformed as a result of human activities, covering industrialized, urbanized and drained areas. In Poland, the regions most transformed are located in the Silesian voivodship. Up to the 1980s high hydrological outflows were observed in the rivers of this region throughout the entire year. After the 1980s, especially during the summer-autumn season lower hydrological outflows were observed as in the case of Kłodnica river (Wrzesiński, 2016). The change of the water regime in the rivers has a deteriorating impact on water quality (Santy et al., 2020).

Despite the implemented multi-million investments involved in reducing the degree of surface water's pollution from anthropogenic sources, the exceeding of permissible concentrations of phosphorus and nitrogen compounds, which is the source of the municipal, industrial and agricultural sectors, is still being identified. The surplus of their load makes it impossible to achieve good status of surface water bodies and to reach the objectives defined in the Water Framework Directive. The problem does not only concern the agricultural catchments but also the highly urbanized areas with a high population concentration. In contrast to the non-urbanized catchments, which show high retention of phosphorus compounds, the urban areas are characterized by rapid transport of nutrients from the catchments to rivers and reservoirs through rainwater (Hobbie et al., 2017). As research has shown (Xia et al., 2016), the impermeable surfaces dominating the urban landscape, from which the sewage is discharged, are the most important factors causing an increase in the concentration of nutrients in surface water bodies. This is mainly due to the small share of wetlands, which play a significant role in removing pollution from the surface waters bodies. As research has shown, among others carried out in Ireland, during which the share of individual sources of pollution in the load discharged from the catchment area was analysed, the main sources of phosphorus come from the sewage treatment plants and agriculture, with large variations across the country - depending on the land use and local hydrogeological conditions (Mockler et al., 2017). Especially the cities climatic conditions and related hydrological conditions have an impact on how pollutants are released and moved. The transport of nitrogen and phosphorus from urban areas to the surface water bodies is closely related to the transport of pollutants in sewage and untreated rainwater. The occurring climate change and prolonged rainless periods result in longer and longer periods of low levels in rivers, which is particularly strongly observed in small watercourses fed from a low-retention urban catchment. The changes in precipitation characteristics will have a strong impact on the nutrient cycle in the catchment areas in the future (Ghane et al., 2016). Since the beginning of the 21 st century, many studies have been conducted to model the impact of land use and climate change on nutrients cycling in the catchments, according to the land-cover and land-use change model - LCLUC (Turner and Geoghegan, 2004; Mustard et al., 2012; Jordan et al., 2014). However, as the German studies (Flügel, 2017) convince, the concept of integrated water resource management (IWRM) does not sufficiently take into account the dynamics of processes associated with the nature of the landscape and the associated LULUC model. The authors of the study propose to improve the approach through integrated management 
of land and water resources (ILWRM), which requires consideration of local specificity. It will be of particular importance to take into account the local specificity at strongly transformed areas as in the above-mentioned article on the case of Upper Silesia, where over two hundred years of mining activity has significantly contributed to the change in the hydrological conditions of the area. Mine waters, due to the wide spectrum of pollution, pose a serious problem from an ecological point of view, which is proved by testing physicochemical parameters, and even more by assessing the quality of the surface waters, based on the ecotoxicological indicators (Zgórska et al., 2016). The climate policy limits the extraction of hard coal and reduces the negative impact on the environment, including water resources. This will cause a number of changes, both positive and negative. The inflow of pollutants from the mine waters (not containing nutrients) will be partially limited, while on the other hand, this will reduce the flow of water in the rivers and increase in the concentration of nutrients in the surface waters. In the selected catchment, the share of mine water is significant. For example, in the Rawa 25\%, Brynica od zb. Kozłowa Góra 26\%, Bytomka as much as $33 \%$ of water in the river with an average flow. For low levels of flow, these values exceed 50\% - own findings based on information from coal mines. Therefore, it seems unavoidable to include the problem of increasing the concentration of nutrients in the surface waters in the water management plans, prepared for the future for the area after total cessation of hard coal mining. Such plans were adopted, among others, in Germany (Drobniewski et al., 2016), Australia (Everingham et al., 2018), or England (Mayes and Jarvis, 2016).

The aim of the study was to determine the influence of phosphorus and nitrogen loads from point and dispersed sources onto the water quality of analysed rivers in Poland.

\section{Material and methods}

The aim of the study was to determine the influence of total phosphorus and total nitrogen loads from point and dispersed sources on the water quality of analysed rivers. For this purpose, the concentrations of phosphorus and nitrogen in selected measurement points within the studied site area were analyzed. Additionally, on the basis of the available data, the amount of nitrogen and phosphorus load discharged into the rivers from point sources (industrial sources, wastewater treatment plants, fishponds) and diffuse sources (agriculture, atmospheric deposition) was determined. A detailed description of the site area, the methodology of collecting samples and analyzing the concentration of nitrogen and phosphorus in the river samples, and calculating the load discharged from each sources are discussed below.

\section{Study area and sampling campaigns}

18 Surface Water Bodies (SWB) located in the area of Upper Silesia in southern Poland were analysed. This region is one of the most urbanized and industrialized regions in Europe (Table 1). The studies covered both heavily built-up catchments located in urban areas, as well as suburban areas with a significant share of agricultural and forest land. The historical and current industrial activity, especially hard coal mining, has an impact on the quality of the environment of the area, including waters.

Most mining companies discharge the mine waters with high concentrations of chlorides and sulphates, and the level of salinity of the water makes it impossible to achieve environmental goals. The results of the tests on the key parameters of quality and quantity of the mine waters from 53 hard coal mines (active and abandoned) have been 
presented in many publications (Bukowski, 2015; Gzyl et al., 2017; Smith and Sobolewski, 2018).

Table 1. Characterisation of analysed River Water Bodies

\begin{tabular}{|c|c|c|c|c|c|c|c|c|c|c|}
\hline \multirow{3}{*}{$\begin{array}{l}\text { River Water } \\
\text { Bodies } \\
\text { (WB) }\end{array}$} & \multirow{2}{*}{\multicolumn{2}{|c|}{\begin{tabular}{|c|}
$\begin{array}{c}\text { Accepted } \\
\text { concentration } \\
\text { related to national } \\
\text { legislation }\end{array}$ \\
$(\mathrm{mg} / \mathrm{l})$ \\
\end{tabular}}} & \multirow[t]{3}{*}{\begin{tabular}{|l|} 
Area \\
(ha) \\
\end{tabular}} & \multirow{2}{*}{\multicolumn{2}{|c|}{ 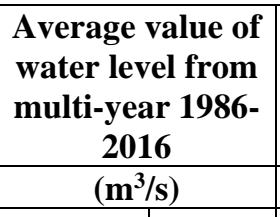 }} & \multirow{2}{*}{\multicolumn{4}{|c|}{$\begin{array}{l}\text { Land use of total } \\
\text { catchment area }\end{array}$}} & \multirow{3}{*}{$\begin{array}{l}\text { Mining } \\
\text { waters } \\
\text { outflow } \\
\end{array}$} \\
\hline & & & & & & & & & & \\
\hline & $\mathbf{N}$ & $\mathbf{P}$ & & $\begin{array}{l}\text { Medium- } \\
\text { Low }\end{array}$ & Medium & \begin{tabular}{|c} 
Urban \\
$\&$ \\
industry
\end{tabular} & Rural & Forest & $\begin{array}{l}\text { Other } \\
\text { incl. } \\
\text { water }\end{array}$ & \\
\hline Potok & 3.4 & 0.2 & 1.22 & 0.061 & 0.124 & 39 & 46 & 15 & 0 & yes \\
\hline Dokawa & 3.2 & 0.2 & 4.33 & 0.081 & 0.357 & 14 & 48 & 37 & 1 & yes \\
\hline $\begin{array}{l}\text { Gostynia do } \\
\text { Starego Koryta }\end{array}$ & 3.2 & 0.2 & 6.64 & 0.334 & 0.675 & 15 & 41 & 42 & 2 & yes \\
\hline Tyski Potok & 4.6 & 0.15 & 2.97 & 0.149 & 0.302 & 44 & 43 & 12 & 1 & yes \\
\hline Bolina & 1.7 & 0.1 & 2.81 & 0.184 & 0.262 & 39 & 6 & 54 & 1 & yes \\
\hline $\begin{array}{l}\text { Dopływ z } \\
\text { Mąkołowca }\end{array}$ & 4.6 & 0.15 & 1.16 & 0.060 & 0.134 & 13 & 31 & 56 & 0 & yes \\
\hline Rawa & 4.6 & 0.15 & 7.15 & 0.813 & 1.181 & 86 & 2 & 11 & 1 & yes \\
\hline Szarlejka & 1.72 & 0.08 & 4.19 & 0.476 & 0.692 & 51 & 19 & 29 & 1 & yes \\
\hline Krzanówka & 3.4 & 0.2 & 1.70 & 0.035 & 0.069 & 13 & 86 & 1 & 0 & no \\
\hline $\begin{array}{c}\text { Lesznica z } \\
\text { Jedłownickim }\end{array}$ & 4.6 & 0.15 & 8.71 & 0.619 & 1.307 & 36 & 52 & 12 & 0 & yes \\
\hline Jamna & 4.6 & 0.15 & 2.31 & 0.124 & 0.266 & 37 & 34 & 27 & 2 & yes \\
\hline $\begin{array}{l}\text { Kłodnica do } \\
\text { Promnej (bez) }\end{array}$ & 4.6 & 0.15 & 7.69 & 0.553 & 1.016 & 36 & 8 & 55 & 1 & yes \\
\hline $\begin{array}{l}\text { Bielszowicki } \\
\text { Potok }\end{array}$ & 4.6 & 0.15 & 3.19 & 0.229 & 0.421 & 68 & 19 & 12 & 1 & yes \\
\hline Bytomka & 4.6 & 0.15 & 14.33 & 1.691 & 2.583 & 49 & 29 & 21 & 1 & yes \\
\hline $\begin{array}{c}\text { Drama do } \\
\text { Grzybowickiego }\end{array}$ & 4.6 & 0.15 & 11.12 & 0.355 & 0.551 & 11 & 76 & 13 & 0 & yes \\
\hline $\begin{array}{l}\text { Kłodnica od } \\
\text { Promnej }\end{array}$ & 2.4 & 0.18 & 4.41 & 0.942 & 1.929 & 68 & 19 & 12 & 1 & yes \\
\hline Lublinica & 3.2 & 0.2 & 11.86 & 0.273 & 0.799 & 10 & 40 & 49 & 1 & no \\
\hline $\begin{array}{c}\text { Brynica od } \\
\text { Kozłowej Góry }\end{array}$ & 2.4 & 0.18 & 9.31 & 3.260 & 5.110 & 52 & 42 & 5 & 1 & yes \\
\hline
\end{tabular}

Research using the Ecological Risk Assessment and bioindication methods (Bondaruk et al., 2015) was also conducted in the area. The area of Upper Silesia is inhabited by nearly 4 million people. This results in a large amount of municipal sewage discharged, largely treated in the installations with an increased degree of the nutrients removal. The hydrological network of the area includes relatively short streams or source sections of the main rivers. A significant impact on the river regime in most of the analysed catchments has the discharge of mine waters, causing an increase in river flow and a direct impact on the physicochemical parameters of water, including a reduction in nutrient concentrations. Only two of the analysed catchments are outside the direct influence of hard coal mining. Table 1 presents a brief description of the analysed catchment areas, including characteristic river flows, catchment area, and the land use structure.

The selection of 18 catchments for the study was based on data and assessment of surface water quality, conducted as part of the State Environmental Monitoring in the 
years 2011-2017. Those cases were chosen, where the failure to achieve good status was determined by exceeding the concentration of nutrients at the monitoring points.

The highest rainfall in Poland is in the period between May and October. The rainfall caused run off of nitrogen and phosphorus into the catchment area. Therefore, the samples of the water river were taken in this period. The tests were carried out in three measurement series at the same points in June 2018 (spring fertilizing), August 2018 (summer fertilizing) and October 2018 (autumn fertilizing). In total, 216 analyses were performed for 72 monitoring points, showed on the map below, except that the collection was carried out at least at two points of each of the SWB covered by the study (Figure 1).

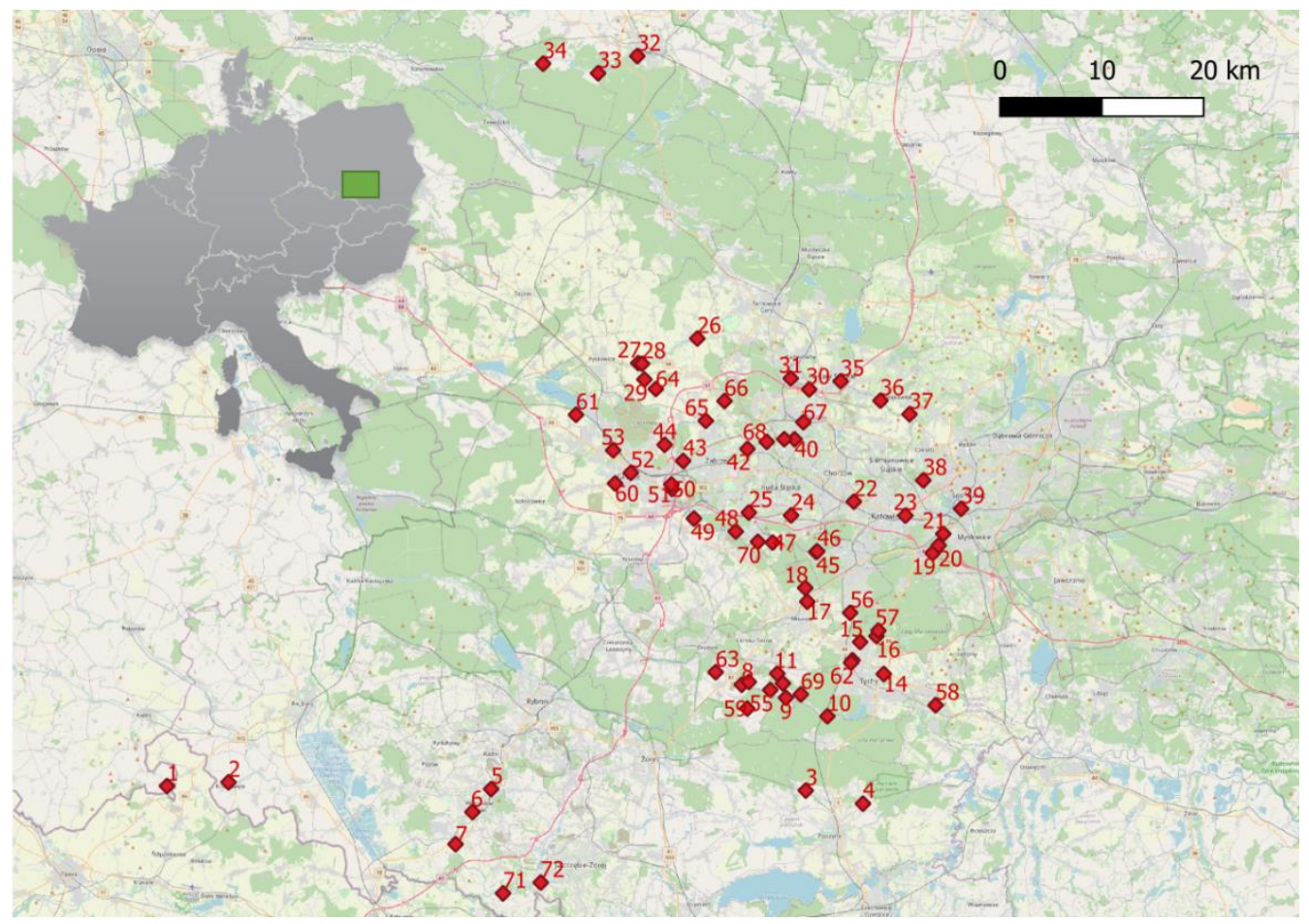

Figure 1. Monitoring points

The study was conducted in the rainless period ( 7 rainless days prior the sampling), for both point and dispersed sources. As part of the study, the determination of total phosphorus and total nitrogen content in the surface waters was performed, and a test of water flow at these points was performed to calculate loads of the tested compounds.

\section{Chemical analysis}

Total phosphorus in the water river probes was determined by the ICP-OES method by using emission plasma spectrometer Optima 5300DV (Perkin Elmer company), total nitrogen in the water river probes was determined by high-temperature combustion with chemiluminescence detection by using analyser of nitrogen content TNM-L (Shimadzu company).

\section{Calculation of nitrogen and phosphorus load in the river}

The load of nitrogen and phosphorus in the measurement points in the rivers was calculated based on the laboratory results and the values of water flow. 


\section{Calculation of nitrogen and phosphorus load discharged from the point sources}

\section{Wastewater Treatment Plants}

The loads from the treated sewage were determined based on data from the National Program for Municipal Sewage Treatment (AKPOŚK, 2017), regarding the volume of the discharged treated sewage and value of the pollution indicators. The calculated values of loads were compared with the values of loads determined based on water law permits and the survey data collected as part of the survey from the water and sewage companies (RME, 2014).

\section{Fishponds}

The calculations of loads of nitrogen and phosphorus for the identified fishponds were carried out based on the data from water permits regarding the volume of discharges and their timeliness.

The data regarding the concentration of pollutants in waters discharged from fishponds were taken on the base of the literature (Bukacińska et al., 1995; Prądzyńska, 2004; Janicka et al., 2018).

\section{Industrial sources}

The loads of nitrogen and phosphorus in the sewage discharging into the watercourses from the identified industrial sources was calculated based on the data from water permits as the volume of discharges (daily, annual), frequency of discharges and permissible concentrations of pollutants in the discharged sewage.

\section{Calculation of nitrogen and phosphorus load discharged from the dispersed sources}

The study on identifying pressures from the dispersed sources was conducted based on the methodology proposed by the Institute of Meteorology and Water Management National Research Institute (IMiGW-PIB, 2013). 3 dispersed sources of nitrogen and phosphorus were identified: agriculture, non-treated sewage and deposition from the atmosphere.

\section{Agriculture - the natural fertilizing}

In order to estimate the amount of N, P from the natural fertilizers, it was assumed that the load of nitrogen and phosphorus was equivalent to the load excreted with urine and faeces of farm animals. Firstly, the number of farm animals and the number of Livestock Unit (LSU) (unit conversion of animals assigned to the analysed catchments) was calculated based on statistical data and information obtained from the Animal Identification and Registration System operated by the Agency for Restructuring and Modernisation of Agriculture. The amount of liquid manure and manure produced in the administration unit was determined based on the number of farm animals and the values specified in Table 7, which is part of the annex to the Council of Ministers Regulation (CMR, 2005). The composition of manure and liquid manure was adopted in accordance with Pająk and Kowalik (2006). According to the methodology of the Institute of Meteorology and Water Management (2013), the amounts of nitrogen and phosphorus outflow to surface waters were determined assuming that the nitrogen outflow factor is 0.5 and the phosphorus outflow factor is 0.2 . 


\section{Agriculture - the mineral fertilizing}

In the first step, the nitrogen surplus was determined based on the nitrogen efficiency factor which was assumed at the level of 0.63 according to the data presented by Kopiński (2017). The nitrogen load discharged from the catchment area was calculated by reducing the surplus value of nitrogen and phosphorus load by the value of the base leaching coefficients. The leaching coefficient of nitrogen was determined according to the method described by Ulen et al. (2013). The value of the coefficient was 0.88 . Due to the low solubility in a wide $\mathrm{pH}$ range, phosphorus is not a very mobile element. Moreover, many regions are deficient in phosphorus. The main mechanism of phosphorus leaching occurs along with surface runoff. About $20 \%$ of phosphorus, which is an excess of phosphorus introduced with mineral fertilizers (remaining in the surface layer of the soil), goes to surface waters. The leaching coefficient of phosphorus was determined according to the method described by the Institute of Meteorology and Water Management (2013). The value of the coefficient was 0.2 .

\section{Atmospheric deposition}

The atmospheric deposition was calculated by multiplying the area of a catchment by the unit load of nitrogen and phosphorus from precipitation per hectare.

The amounts of nitrogen and phosphorus was determined based on reports on the state of the environment (Liana et al., 2017) and the data from rainwater monitoring stations Katowice and Racibórz.

\section{Non-treated sewage sludge}

The loads from the non-treated sewage were determined on the base of data from the National Program for Municipal Sewage Treatment (AKPOŚK, 2017), regarding the volume of the discharged non-treated sewage and the values of pollution indicators in the discharged non-treated sewage.

\section{Results and discussion}

\section{Nitrogen and phosphorus load from the point sources}

Based on the above-described method the loads of total phosphorus and total nitrogen discharged within a year from the point sources (PS) to the individual SWB were calculated (NPS - Load of Nitrogen from Point Sources, PPS - Load of Phosphorus from Point Sources). The following table shows the results of the calculated load (Table 2).

The highest values are directly related to the volume of the municipal sewage discharged from the catchment. Therefore, the largest loads from the point sources come from the highly urbanized catchments. For example, in the Bytomka catchment, there are 7 municipal sewage treatment plants discharging sewage from 3 cities, and the total length of the river is only $19 \mathrm{~km}$. The analysis of average annual flows in the Bytomka catchments in the period from 1970-1992 showed an increase in water flows, despite the fact that rainfall shortages were observed in the period from 1984-1992. The high water flow values at that time was coincided with the maximum demand for water by industrial and municipal services, which resulted in increased amounts of wastewater discharged into these rivers. In the second half of the 1980s, significant discharges of mine waters were also observed, in the case of Bytomka $0.8871 \mathrm{~m}^{3} / \mathrm{s}$ of mine waters was dumped, which accounted for over $30 \%$ of the average annual flow. The amount of mine water 
discharged has been steadily decreasing since 1990. As a result of the decrease in average annual flows in Bytomka, despite the smaller amount of mine water discharged, their ratio in the average annual flows increased to $40-50 \%$. Such a high ratio of mining waste water in the outflow of these rivers indicates their high impact on their water quality (Absalon and Matysik, 2016). The results showed the high impact of industrial point sources on the quality of water in the highly urbanized catchments (Bolina, Bytomka, Kłodnica do Promnej, Kłodnica od Promnej) (Table 2).

Table 2. Compounds of phosphorus and nitogen loads and total loads of phosphorus and total nitrogen

\begin{tabular}{|c|c|c|c|c|c|c|c|c|}
\hline \multirow{4}{*}{$\begin{array}{l}\text { River Water } \\
\text { Body }\end{array}$} & \multicolumn{6}{|c|}{ Source } & \multirow{3}{*}{ Total N } & \multirow{3}{*}{ Total P } \\
\hline & \multicolumn{2}{|c|}{ Industry } & \multicolumn{2}{|c|}{ Sewage } & \multicolumn{2}{|c|}{ Ponds } & & \\
\hline & $\mathbf{N}$ & $\mathbf{P}$ & $\mathbf{N}$ & $\mathbf{P}$ & $\mathbf{N}$ & $\mathbf{P}$ & & \\
\hline & \multicolumn{8}{|c|}{$\mathrm{kg}^{*} 10^{3} / \mathrm{y}$} \\
\hline Krzanówka & 0 & 0 & 0 & 0 & 0 & 0 & $\mathbf{0}$ & $\mathbf{0}$ \\
\hline Dokawa & 0.1 & 0.008 & 0 & 0 & 7,209 & 0.005 & 7.3 & 0.013 \\
\hline Lesznica z Jedłownickim & 0 & 0 & 56.9 & 3.7 & 0 & 0 & 56.9 & 3.7 \\
\hline Gostynia do starego koryta & 0.02 & 0.002 & 4.5 & 1.8 & 0 & 0 & 4.6 & 1.8 \\
\hline Potok & 0 & 0 & 13.7 & 0.9 & 0 & 0 & 133.7 & 0.9 \\
\hline Tyski Potok & 0 & 5.0 & 0 & 0 & 0 & 0 & 0 & 5.0 \\
\hline Dopływ z Mąkołowca & 0 & 0 & 0 & 0 & 0 & 0 & $\mathbf{0}$ & $\mathbf{0}$ \\
\hline Jamna & 0 & 0 & 38.3 & 1.6 & 0 & 0 & 38.2 & 1.6 \\
\hline Bolina & 21.5 & 2.1 & 0 & 0 & 0 & 0 & 21.5 & 2.1 \\
\hline Rawa & 0 & 0 & 198.8 & 10.5 & 0 & 0 & 198.8 & 10.5 \\
\hline Bielszowicki Potok & 1.9 & 0.2 & 25.4 & 1.9 & 0 & 0 & 27.3 & 2.1 \\
\hline Drama do Grzybowickiego & 4.5 & 0.4 & 13.8 & 0.6 & 0 & 0 & 18.2 & 1.0 \\
\hline Szarlejka & 0 & 0.002 & 70.6 & 4.7 & 0 & 0 & 70.6 & 4.7 \\
\hline Lublinica & 0 & 0 & 24.4 & 0.7 & 0 & 0 & 24.4 & 0.7 \\
\hline Brynica od zb. Kozłowa Góra & 0.2 & 2.4 & 181.9 & 3.5 & 0 & 0 & 182.1 & 5.9 \\
\hline Bytomka & 1.3 & 32.5 & 147.6 & 1.9 & 0 & 0 & 148.9 & 34.4 \\
\hline Kłodnica do Promnej & 7.1 & 0.7 & 104.3 & 3.4 & 0 & 0 & 111.4 & 4.1 \\
\hline Kłodnica od Promnej & 2.1 & 0.2 & 116.5 & 6.9 & 0 & 0 & 118.6 & 7.1 \\
\hline
\end{tabular}

In the case of the Rawa River with a length of about $20 \mathrm{~km}$, the calculated total nitrogen load discharged every year from the sewage treatment plant reaches almost $200 \mathrm{t} / \mathrm{y}$ (Table 2).

The treated sewage caused the increase of nutrient load in the water rivers, especially in catchments of Rawa, Brynica od zb. Kozłowa Góra, Bytomka, Kłodnica do Promnej and Kłodnica od Promnej (Table 2), despite the fact that the quality of treated sewage meets the legal requirements (RME, 2014). This phenomenon is especially observed in catchments where climate change causes variation in the water regime. The decreased amount of rainfall has an impact on water resources as well as on water supply and sanitation facilities. During rainless periods low flows in surface waters can be observed and the treated sewage in rivers becomes less diluted causing contamination issues. The increased intensity of rainfall also has a deteriorating impact on water quality.

The following table shows the results of the calculated load for the individual types of dispersed sources. Several SWB have been identified to which untreated sewage is discharged, such as Lesznica z Jedłownickim; Gostynia do starego koryta, Drama do 
Grzybowickiego, Kłodnica od Promnej. The annual nitrogen and phosphorus load from these sources varied respectively between $0.8-6.5 \mathrm{MgN} / \mathrm{y}$ and $0.1-1 \mathrm{MgP} / \mathrm{y}$ (Table 3).

Table 3. Load for the individual types of dispersed sources

\begin{tabular}{|c|c|c|c|c|c|c|c|c|c|c|}
\hline \multirow{3}{*}{$\begin{array}{c}\begin{array}{c}\text { Type of nitrogen } \\
\text { and phosphorus } \\
\text { source }\end{array} \\
\text { Water Body }\end{array}$} & \multicolumn{2}{|c|}{$\begin{array}{l}\text { Mineral } \\
\text { Fertilizer }\end{array}$} & \multicolumn{2}{|c|}{$\begin{array}{l}\text { Natural } \\
\text { Fertilizer }\end{array}$} & \multicolumn{2}{|c|}{$\begin{array}{c}\text { Non- } \\
\text { treatment } \\
\text { sewage }\end{array}$} & \multicolumn{2}{|c|}{$\begin{array}{l}\text { Atmospheric } \\
\text { deposition }\end{array}$} & \multicolumn{2}{|c|}{ Total } \\
\hline & $\mathbf{N}$ & $\mathbf{P}$ & $\mathbf{N}$ & $\mathbf{P}$ & $\mathbf{N}$ & $\mathbf{P}$ & $\mathbf{N}$ & $\mathbf{P}$ & $\Sigma \mathbf{N}$ & $\Sigma \mathbf{P}$ \\
\hline & \multicolumn{10}{|c|}{$\mathrm{kg}^{2} 10^{3} / \mathrm{y}$} \\
\hline Krzanówka & 30.7 & 1.6 & 38.6 & 9.7 & & & 14.7 & 0.2 & 84.0 & 11.5 \\
\hline Dokawa & 43.7 & 2.0 & 54.0 & 13.8 & & & 49.0 & 1.0 & 146.8 & 16.9 \\
\hline $\begin{array}{l}\text { Lesznica z } \\
\text { Jedłownickim }\end{array}$ & 94.1 & 4.3 & 117.1 & 29.7 & 6.5 & 1.0 & 90.8 & 1.7 & 308.5 & 36.7 \\
\hline $\begin{array}{l}\text { Gostynia do } \\
\text { starego koryta }\end{array}$ & 56.1 & 2.6 & 69.9 & 17.7 & 0.8 & 0.1 & 70.9 & 1.6 & 197.7 & 22.1 \\
\hline Potok & 9.2 & 0.5 & 14.4 & 3.7 & & & 13.0 & 0.3 & 36.7 & 4.5 \\
\hline Tyski Potok & 40.9 & 1.2 & 33.9 & 8.6 & & & 30.2 & 0.7 & 105.0 & 10.5 \\
\hline $\begin{array}{l}\text { Dopływ z } \\
\text { Mąkołowca }\end{array}$ & 11.4 & 0.3 & 9.5 & 2.4 & & & 11.8 & 0.3 & 32.7 & 3.0 \\
\hline Jamna & 16.4 & 0.7 & 20.5 & 5.2 & & & 23.5 & 0.5 & 60.4 & 6.4 \\
\hline Bolina & 3.4 & 0.2 & 4.2 & 1.12 & & & 26.2 & 0.6 & 33.7 & 1.8 \\
\hline Rawa & 3.1 & 0.1 & 3.8 & 9.7 & & & 69.1 & 1.5 & 76.0 & 2.6 \\
\hline Bielszowicki Potok & 9.8 & 0.6 & 15.4 & 3.9 & & & 32.5 & 0.7 & 57.7 & 5.2 \\
\hline $\begin{array}{c}\text { Drama do } \\
\text { Grzybowickiego }\end{array}$ & 7.6 & 0.3 & 9.5 & 2.4 & & & 11.5 & 0.2 & 29.4 & 3.1 \\
\hline Szarlejka & 12.0 & 0.7 & 18.9 & 4.8 & & & 40.5 & 0.9 & 71.4 & 6.4 \\
\hline Lublinica & 97.1 & 4.5 & 120.9 & 30.7 & & & 117.8 & 0.3 & 335.8 & 37.8 \\
\hline $\begin{array}{l}\text { Brynica od zb. } \\
\text { Kozłowa Góra }\end{array}$ & 80.8 & 3.7 & 100.6 & 25.5 & & & 89.9 & 2.0 & 271.4 & 31.2 \\
\hline Bytomka & 69.0 & 4.0 & 108.5 & 27.6 & & & 139.2 & 3.1 & 316.8 & 34.6 \\
\hline $\begin{array}{l}\text { Kłodnica do } \\
\text { Promnej }\end{array}$ & 12.7 & 0.6 & 15.8 & 4.0 & & & 77.4 & 1.6 & 105.9 & 6.2 \\
\hline $\begin{array}{l}\text { Kłodnica od } \\
\text { Promnej }\end{array}$ & 13.9 & 0.8 & 21.8 & 5.5 & 1.3 & 0.2 & 38.8 & 0.8 & 75.9 & 7.4 \\
\hline
\end{tabular}

$\mathrm{X}-$ no exiting non-treatment sewage

In the case of dispersed sources in the urban catchments, the load related to atmospheric deposition dominates, as well as the load resulting from the runoff of waters contaminated with nitrogen and phosphorus compounds, coming from the natural fertilization used in the agricultural areas and/or the use of mineral fertilizers.

The increase in the amount of nitrogen and phosphorus in the atmospheric precipitation may be caused by the progressive changes in the climate, which affect the plant growth and biochemical cycling. Climate change and nutrient deposition can also have interacting effects. The high amount of nitrogen and phosphorus in precipitation can lead to plant growth potentially enhancing their responsiveness to changes in climate. The results have also showed a great impact of agriculture on the water resources. The precipitation flush mineral fertilizer, manure or liquid manure into water river. It is especially dangerous due to the progressive climate change and more and more frequent occurrence of unfavorable phenomena such as extreme precipitation and flooding. The excess water increase nitrogen flushed from agricultural systems and will pose greater risks to environmental stability of water. The nutrient rich-water are prone to algal blooms which on the other hand are responsible for massive fish kills (Glibert, 2020). 
The following graph presents the share of total nitrogen and total phosphorus in the annual load (Figure 2). In most of the analysed cases, the area and dispersed sources are a definitely larger source of this group of pollutants (N_DS - Load of Nitrogen from Dispersed Sources, P_DS - Load of Phosphorus from Dispersed Sources). In the case of catchments with a lower degree of urbanization, the role of this type of source is dominant in an unequivocal way.

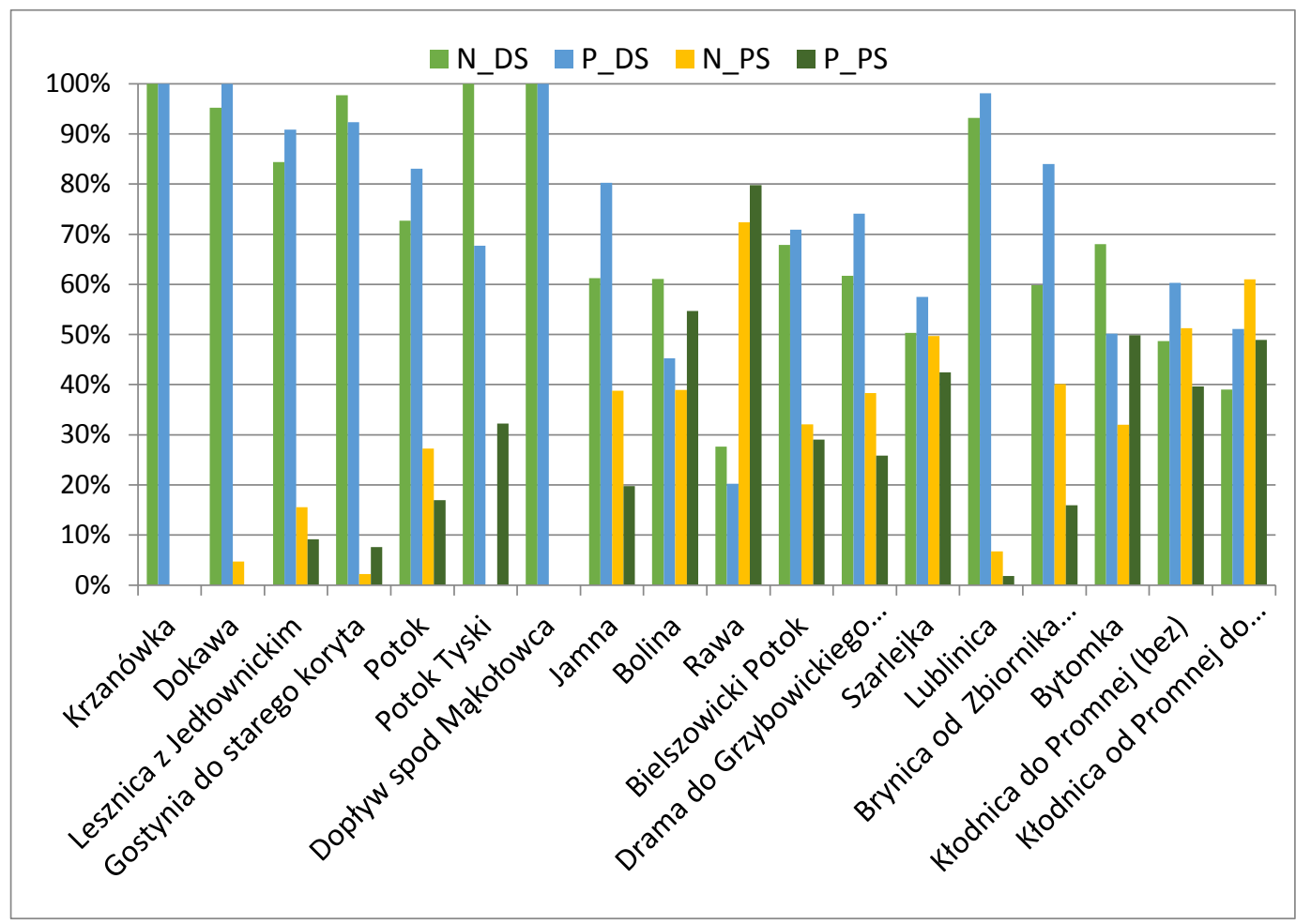

Figure 2. The share of total nitrogen and total phosphorus in the annual load

In order to assess how the calculated maximum value of nitrogen and phosphorus loads discharged from all analyzed point sources affect the water quality, a negative scenario was adopted for the analysis. It was assumed that the water flow has low or medium level.

The results showed that in almost all analyzed SWB, the nitrogen and phosphorus loads are too large and exceeds the allowable limit (RME, 2016) (Table 4). To determine the degree of necessary reduction of nutrient, the threshold values relevant to the types of individual SWB were adopted. The degree of reduction was defined as the difference between the load discharged to a SWB, and the load that could be the maximum discharged to SWB.

The analysis of results presented in the Table 4 indicates, that in the case when the nitrogen and phosphorus load will be at maximum allowable level (specified in the water permits) in the scenario with low-medium flow in the watercourses any of the analysed SWB will not obtain a good status. The permissible phosphorus concentration in the analysed watercourses will be exceeded many times. In the event of medium-level flows, the permissible concentrations of pollutants will not be exceeded only in two of the 18 analysed SWB. 
Table 4. Required degree of reduction of phosphorus and nitrogen compounds

\begin{tabular}{|c|c|c|c|c|c|c|c|c|c|c|}
\hline \multirow{3}{*}{$\begin{array}{l}\text { River Water } \\
\text { Body }\end{array}$} & \multicolumn{4}{|c|}{$\begin{array}{l}\text { Limit to good status of WB } \\
\qquad \mathrm{kg}^{*} 10^{3} / \mathrm{y}\end{array}$} & \multirow{2}{*}{\multicolumn{2}{|c|}{$\begin{array}{l}\text { Real load } \\
\mathrm{kg}^{*} 10^{3} / \mathrm{y}\end{array}$}} & \multicolumn{4}{|c|}{$\begin{array}{c}\text { Requested reduction } \\
\mathrm{kg}^{*} 10^{3} / \mathrm{y}\end{array}$} \\
\hline & \multicolumn{2}{|c|}{ medium flow } & \multicolumn{2}{|c|}{$\begin{array}{l}\text { medium-low } \\
\text { flow }\end{array}$} & & & \multicolumn{2}{|c|}{ medium flow } & \multicolumn{2}{|c|}{ medium-low flow } \\
\hline & $\mathbf{N}$ & $\mathbf{P}$ & $\mathbf{N}$ & $\mathbf{P}$ & $\mathbf{N}$ & $\mathbf{P}$ & $\mathbf{N}$ & $\mathbf{P}$ & $\mathbf{N}$ & $\mathbf{P}$ \\
\hline Potok & 32.1 & 1.6 & 15.8 & 0.5 & 50.4 & 5.4 & 18.3 & 3.8 & 34.6 & 4.9 \\
\hline Dokawa & 55.2 & 3.4 & 12.5 & 0.4 & 154.1 & 16.9 & 98.8 & 13.5 & 141.5 & 16.5 \\
\hline $\begin{array}{c}\text { Gostynia do } \\
\text { starego koryta }\end{array}$ & 104.4 & 6.4 & 51.6 & 1.6 & 202.3 & 23.9 & 97.9 & 17.5 & 150.6 & 22.3 \\
\hline Potok Tyski & 65.8 & 3.3 & 32.4 & 1.0 & 105.0 & 15.5 & 39.3 & 12.2 & 72.6 & 14.5 \\
\hline Bolina & 25.6 & 1.7 & 18.0 & 0.6 & 55.2 & 3.9 & 29.6 & 2.2 & 37.2 & 3.4 \\
\hline $\begin{array}{l}\text { Dopływ spod } \\
\text { Mąkołowca }\end{array}$ & 29.2 & 1.5 & 13.1 & 0.4 & 32.7 & 3.0 & 3.5 & 1.5 & 19.7 & 2.6 \\
\hline Rawa & 257.2 & 13.0 & 177.0 & 5.6 & 274.8 & 13.1 & 17.6 & 0.1 & 97.8 & 7.5 \\
\hline Szarlejka & 76.4 & 6.8 & 52.6 & 1.7 & 142.0 & 11.1 & 65.6 & 4.4 & 89.4 & 9.5 \\
\hline Krzanówka & 17.9 & 0.9 & 9.1 & 0.3 & 84.1 & 11.5 & 66.2 & 10.6 & 75.0 & 11.2 \\
\hline $\begin{array}{l}\text { Lesznica z } \\
\text { Jedłownickim }\end{array}$ & 284.6 & 14.4 & 134.8 & 4.3 & 365.4 & 40.4 & 80.8 & 26.0 & 230.7 & 36.2 \\
\hline Jamna & 57.9 & 2.9 & 27.0 & 0.9 & 98.7 & 8.0 & 40.8 & 5.1 & 71.7 & 7.2 \\
\hline $\begin{array}{l}\text { Kłodnica do } \\
\text { Promnej (bez) }\end{array}$ & 221.2 & 11.2 & 120.4 & 3.8 & 217.3 & 10.4 & -3.9 & -0.9 & 96.9 & 6.6 \\
\hline $\begin{array}{l}\text { Bielszowicki } \\
\quad \text { Potok }\end{array}$ & 91.7 & 4.6 & 49.9 & 1.6 & 85.1 & 7.3 & -6.6 & 2.7 & 35.2 & 5.7 \\
\hline $\begin{array}{l}\text { Bytomka } \\
\text { Drama do }\end{array}$ & 562.4 & 28.5 & 368.2 & 11.6 & 465.7 & 69.1 & -96.7 & 40.6 & 97.5 & 57.5 \\
\hline $\begin{array}{l}\text { Grzybowickiego } \\
\text { Potoku włącznie }\end{array}$ & 120.0 & 6.1 & 77.3 & 2.4 & 47.6 & 4.2 & -72.3 & -1.8 & -29.7 & 1.8 \\
\hline $\begin{array}{l}\text { Kłodnica od } \\
\text { Promnej do } \\
\text { Kozłówki }\end{array}$ & 182.6 & 13.4 & 89.2 & 2.8 & 194.5 & 14.5 & 11.9 & 1.1 & 105.3 & 11.7 \\
\hline $\begin{array}{c}\text { Lublinica } \\
\text { Brynica od zb. }\end{array}$ & 120.5 & 7.4 & 42.2 & 1.3 & 360.2 & 38.5 & 239.8 & 31.1 & 318.0 & 37.2 \\
\hline $\begin{array}{c}\text { Kozłowa Góra do } \\
\text { ujścia }\end{array}$ & 483.8 & 35.5 & 308.6 & 9.7 & 453.6 & 37.2 & -30.2 & 1.7 & 144.9 & 27.5 \\
\hline
\end{tabular}

\section{Conclusions}

Due to climate change, nitrogen and phosphorus loads discharged into waters from different sources have a greater impact on the quality of these waters. This is due to the change in the water regime in watercourses. The occurrence of long rainless periods causes the reduction of the flow of water in water courses and as a result of the decrease in average annual flows even when the amount of nitrogen and phosphorus discharged is at the allowable level, their ratio in the average annual flows is too high. Moreover, the forecasting limitation of mine water outflow will cause that water level in selected water bodies to decrease in some cases by more than half. Due to that, it is important in the environmental management plans of the post-mining area to take into account the use of a part of the mine water to perform regulatory functions in the environment.

At the same time, due to the climate change, the occurrence of extreme precipitation, causing flush of a high amount of nutrients from the fertilizing soil should also be considered. The solution to this problem may be intelligent fertilization, which will 
reduce the phenomenon of over-fertilization and discharge of excess nutrients with rainwater to the catchment.

As in the other areas, a significant ratio of the atmospheric deposition in the transfer of nutrients into water bodies was found. In the periods of low water flows, the impact of the dispersed sources of nutrients on water quality is smaller due to the lack of atmospheric precipitation. The share of deposition of these pollutants from the atmosphere is at zero level, and the surface runoff and infiltration from the topsoil layers are negligible. The results show also the impact of the sewage discharged from fishpond on the quality of the water river. This source of pollution has a particular impact on water reservoirs, as the ponds are drained only once a year. It is recommended to pretreat water from fishponds before introducing them into water courses.

The treated wastewater has also an impact on the water quality but the level of nutrient reduction in the sewage treatment plants will no longer be significantly improved, the efforts should be focused on solutions in the catchment area, including the water management and landscaping.

Further analysis should be done taking into account the amount of precipitation and flows in water courses throughout the year. The results of the research would allow to determine the model of the influence of various sources of pollution in the variable flow conditions. This tool would be useful for predicting the impact of nitrogen and phosphorus loads on water bodies quality with regard to the climate change.

Acknowledgements. This work was supported by the Ministry of Science and Higher Education, Republic of Poland (Statutory Activity of the Central Mining Institute in Katowice, Poland. Work no. 14508018344).

\section{REFERENCES}

[1] Absalon, D., Matysik, M. (2016): Zmiany odpływu w silnie zurbanizowanych zlewniach województwa śląskiego. - In: Hejduk, L., Kaznowska, E. (eds.) Hydrologia Zlewni Zurbanizowanych. Monografie Komitetu Gospodarki Wodnej PAN, 39, KGW-PAN, IMGW-PIB, Warszawa.

[2] Bondaruk, J., Janson, E., Wysocka, M., Chałupnik, S. (2015): Identification of hazards for water environment in the Upper Silesian Coal Basin caused by the discharge of salt mine water containing particularly harmful substances and radionuclides. - Journal of Sustainable Mining 14(4): 179-187.

[3] Bukacińska, M., Bukaciński, D., Cygan, J. P., Dobrowolski, K. A. (1995): Natural and economic valorisation of fishponds in Poland. - Foundation IUCN Poland Warszawa; Przyrodniczo-ekonomiczna waloryzacja stawów rybnych w Polsce, Fundacja IUCN Poland Warszawa.

[4] Bukowski, P. (2015): Evaluation of water hazard in hard coal mines in changing conditions of functioning of mining industry in Upper Silesian Coal Basin-USCB (Poland). Archives of Mining Sciences 60(2): 455-475.

[5] CRE (2015): Regulation of the Council of Ministers of 18 May 2005 amending the regulation on detailed conditions and procedures for granting financial aid for the adaptation of agricultural holdings to the standards of the European Union covered by the rural development plan. - Journal of Laws 93: 780.

[6] Czernecki, B., Miętus, M. (2017): The thermal seasons variability in Poland, 1951-2010. - Theoretical and Applied Climatology 127(1-2): 481-493. 
[7] Drobniewski, M., Balzer, I., Frankenhoff, H., Witthaus, H. (2016): Mine Water Management in the Ruhr coalfield. - Proceedings of the IMWA symposium 2016, IMWA Leipzig (Germany).

[8] Everingham, J. A., Rolfe, J., Lechner, A. M., Kinnear, S., Akbar, D. (2018): A proposal for engaging a stakeholder panel in planning post-mining land uses in Australia's coal-rich tropical savannahs. - Land use policy 79: 397-406.

[9] Flügel, W. A. (2017): River Basin Impact Assessment of Changing Land Use and Climate by Applying the ILWRM Approach in Africa and Asia. - River System Analysis and Management. Springer, Singapore, pp. 85-112.

[10] Ghane, E., Ranaivoson, A. Z., Feyereisen, G. W., Rosen, C. J., Moncrief, J. F. (2016): Comparison of contaminant transport in agricultural drainage water and urban storm water runoff. - PloS one 11(12): e0167834.

[11] Glibert, P. M. (2020): Harmful algae at the complex nexus of eutrophication and climate change. - Harmful Algae 91: 101583.

[12] GUS (2016): CentralStatitical Office. - available on-line: 26.10.2020. https://stat.gov.pl/obszary-tematyczne/rolnictwo-lesnictwo/rolnictwo/.

[13] GUS (2017): CentralStatitical Office. - available on-line: 26.10.2020. https://stat.gov.pl/obszary-tematyczne/rolnictwo-lesnictwo/rolnictwo/.

[14] Gzyl, G., Janson, E., Łabaj, P. (2017): Mine Water Discharges in Upper Silesian Coal Basin (Poland). - In: Bech, J., Bini, C., Pashkevich, M. A. (eds.) Assessment, Restoration and Reclamation of Mining Influenced Soils. Academic Press, pp. 463-486

[15] Hobbie, S. E., Finlay, J. C., Janke, B. D., Nidzgorski, D. A., Millet, D. B., Baker, L. A. (2017): Contrasting nitrogen and phosphorus budgets in urban watersheds and implications for managing urban water pollution. - Proceedings of the National Academy of Sciences 114(16): 4177-4182.

[16] IMiGW-PIB (2013): Developing an analysis of pressures and impacts of the anthropogenic pollution in a detailed approach to all water categories for the purposes of developing update of action programs and water management plans: "Methodology defining procedures for identifying pressures and assessing influences/impacts and the risk of failing to achieve the environmental objectives for all the surface water categories". - data access 12.11.2019.

[17] IPCC (2007): Fourth Assessment Report SPM: Climate Change. - Intergovernmental Panel on Climate Change.

[18] IPCC (2013): Fifth Assessment Report SPM: Climate Change. - Intergovernmental Panel on Climate Change.

[19] Janicka, E., Kanclerz, J., Jany, J., Adamska, A., Murat-Błażejewska, S. (2018): Assessment of water quality and nutrient balance of a small lake in urban landscape-case study of Rusałka lake in the Wielkopolskie Lakeland. - Annals of Warsaw University of Life Sciences-SGGW, Land Reclamation 50(3): 229-239.

[20] Jordan, Y. C., Ghulam, A., Chu, M. L. (2014): Assessing the Impacts of Future Urban Development Patterns and Climate Changes on Total Suspended Sediment Loading in Surface Waters Using Geoinformatics. - Journal of Environmental Informatics 24(2).

[21] Journal of Laws (2016): Regulation of the Minister of Environment of 21 July 2016 on the classification of bodies of surface water and environmental quality standards for priority substances. - Item 118-7.

[22] Kopiński, J. (2017): Ocena zmian efektywności wykorzystania azotu w produkcji rolniczej Polski. - Roczniki Naukowe Stowarzyszenia Ekonomistów Rolnictwa i Agrobiznesu 19(1): 85-91.

[23] KPOŚK (2018): Report on the implementation of the National Program for Urban Waste Water Treatment. - https://dane.gov.pl, available on-line: 26.10.2020.

[24] Liana, E., Błachuta, J., Kolanek, A., Terlecka, E., Pobudejski, M., Miszuk, B., Otop, I., Mazurek, M., Rawa, W. (2017): Monitoring Chemizmu Opadów atmosferycznych i ocena 
depozycji zanieczyszczeń do podłoża w latach 2016-2018. - Inspekcja Ochrony Środowiska, Wrocław.

[25] Malinowski, Ł., Skoczko, I. (2018): Impacts of Climate Change on Hydrological Regime and Water Resources Management of the Narew River in Poland. - Journal of Ecological Engineering 19(4): 167-175.

[26] Mayes, M., Jarvis, A. P. (2016): Mine water outbreak and stability risks: examples and challenges from England and Wales. - Proceedings IMWA 2016, Freiberg Germany, pp. 1078-1083.

[27] Mockler, E. M., Deakin, J., Archbold, M., Gill, L., Daly, D., Bruen, M. (2017): Sources of nitrogen and phosphorus emissions to Irish rivers and coastal waters: estimates from a nutrient load apportionment framework. - Science of the Total Environment 601: 326-339.

[28] Mustard, J. F., Defries, R. S., Fisher, T., Moran, E. (2012): Land-use and land-cover change pathways and impacts. - In: Gutman, G., Janetos, A. C., Justice, C. O., Moran, E. F., Mustard, J. F., Rindfuss, R. R., Skole, D., Turner II, B. L., Cochrane, M. A. (eds.) Land change science. Springer, Dordrecht, pp. 411-429.

[29] Pająk, J. J., Kowalik, B. (2006): Wpływ żywienia i systemu utrzymania zwierząt na ilość i skład odchodów od bydła. - Nawozy i nawożenie 4(29): 7-19.

[30] Prądzyńska, D. (2004): Próba oceny oddziaływania stawów hodowlanych na środowisko przyrodnicze (na przykładzie gminy Malechowo). - Problemy Ecologii Krajobrazu 13: 219-224.

[31] Qian, Ch., Fu, C., Wu, Z. (2011): Changes in the Amplitude of the Temperature Annual Cycle in China and Their Implication for Climate Change Research. - Journal of Climate 24(20): 5292-5302.

[32] RME (2014): Regulation of the Minister of the Environment of 18 November 2014 on the conditions to be met when discharging sewage into waters or into the ground, and on substances particularly harmful to the aquatic environment. - Journal of Laws 2014, item 1800.

[33] RME (2016): Regulation of the Minister of the Environment of July 21, 2016 on the method of classification of the status of the surface water bodies and the environmental quality standards for the priority substances. - Journal of Laws 2016, item 118.

[34] Santy, S., Mujumdar, P., Bala, G. (2020): Potential Impacts of Climate and Land Use Change on the Water Quality of Ganga River around the Industrialized Kanpur Region. Scientific Reports 10: 9107.

[35] Smith, H. L., Sobolewski, M. (2018): The Saline Water Problem in Upper Silesia. - In: Jasinski, P., Smith, H. L. (eds.) Environmental Regulation in Transforming Economies: The Case of Poland. London, 374p.

[36] Tomalski, P. (2016): Sezonowa zmienność stanów wód podziemnych w dolinie Sokołówki (Łódź). - In: Hejduka, L., Kaznowskiej, E. (eds.) Hydrologia Zlewni Zurbanizowanych. Monografie Komitetu Gospodarki Wodnej PAN, 39, KGW-PAN, IMGW-PIB, Warszawa.

[37] Turner, B. L., Geoghegan, J. (2004): Land-Cover and Land-Use Change (LCLUC) in the Southern Yucatán Peninsular Region (SYPR). - In: Fox, J., Rindfuss, R. R., Walsh, S. J., Mishra, V. (eds.) People and the Environment. Springer, Boston, MA, pp. 31-60.

[38] Ulén, B., Pietrzak, S., Tonderski, K. S. (2013): Samoocena gospodarstw w zakresie zarządzania składnikami nawozowymi i oceny warunków środowiskowych. - Instytut Technologiczno-Przyrodniczy w Falentach.

[39] Wrzesiński, D. (2016): Zmiany reżimu odpływu rzecznego w Polsce. - In: Hejduka, L., Kaznowskiej, E. (eds.) Hydrologia Zlewni Zurbanizowanych. Monografie Komitetu Gospodarki Wodnej PAN, 39, KGW-PAN, IMGW-PIB, Warszawa.

[40] Xia, Y., Ti, C., She, D., Yan, X. (2016): Linking river nutrient concentrations to land use and rainfall in a paddy agriculture-urban area gradient watershed in southeast China. Science of the Total Environment 566: 1094-1105. 
[41] Yang, Y. Y., Toor, G. S. (2017): Sources and mechanisms of nitrate and orthophosphate transport in urban storm water runoff from residential catchments. - Water research 112: 176-184.

[42] Zgórska, A., Trząski, L., Wiesner, M. (2016): Environmental risk caused by high salinity mine water discharges from active and closed mines located in the Upper Silesian Coal Basin (Poland). - Proceedings IMWA 2016: 85.

\section{APPENDIX}

Appendix 1. Coordinates of monitoring points

\begin{tabular}{|c|c|c|}
\hline \multirow{2}{*}{ Monitoring points } & \multicolumn{2}{|c|}{ EPSG 2180} \\
\hline & $\mathbf{X}$ & $\mathbf{Y}$ \\
\hline 1 & 430853 & 239375 \\
\hline 2 & 436895 & 239746 \\
\hline 3 & 493580 & 238931 \\
\hline 4 & 499197 & 237648 \\
\hline 5 & 462683 & 239078 \\
\hline 6 & 460855 & 236824 \\
\hline 7 & 459192 & 233667 \\
\hline 8 & 487293 & 249319 \\
\hline 9 & 491638 & 248035 \\
\hline 10 & 495705 & 246219 \\
\hline 11 & 490784 & 250412 \\
\hline 12 & 491339 & 249446 \\
\hline 13 & 498173 & 251719 \\
\hline 14 & 501239 & 250372 \\
\hline 15 & 498921 & 253510 \\
\hline 16 & 500524 & 254082 \\
\hline 17 & 493728 & 257463 \\
\hline 18 & 493534 & 258810 \\
\hline 19 & 506042 & 262227 \\
\hline 20 & 506630 & 262988 \\
\hline 21 & 507091 & 264122 \\
\hline 22 & 498303 & 267282 \\
\hline 23 & 503365 & 265917 \\
\hline 24 & 492138 & 265936 \\
\hline 25 & 487989 & 266212 \\
\hline 26 & 482935 & 283291 \\
\hline 27 & 477130 & 280880 \\
\hline 28 & 477504 & 280811 \\
\hline 29 & 477737 & 279268 \\
\hline 30 & 493913 & 278294 \\
\hline 31 & 492109 & 279378 \\
\hline 32 & 477033 & 311006 \\
\hline 33 & 473184 & 309322 \\
\hline 34 & 467788 & 310260 \\
\hline 35 & 497004 & 279097 \\
\hline 36 & 500914 & 277192 \\
\hline 37 & 503770 & 275861 \\
\hline 38 & 505122 & 269372 \\
\hline 39 & 508834 & 266584 \\
\hline 40 & 492486 & 273408 \\
\hline 41 & 491470 & 273416 \\
\hline 42 & 487858 & 272459 \\
\hline 43 & 481539 & 271278 \\
\hline 44 & 479729 & 272860 \\
\hline 45 & 494603 & 262345 \\
\hline 46 & 494711 & 262400 \\
\hline 47 & 490326 & 263273 \\
\hline
\end{tabular}



context of climate change - case study in Poland

$$
\text { - } 1048 \text { - }
$$

\begin{tabular}{c|c|c}
\hline \multirow{2}{*}{ Monitoring points } & \multicolumn{2}{|c}{ EPSG 2180 } \\
\cline { 2 - 3 } & $\mathbf{X}$ & Y \\
48 & 486708 & 264351 \\
50 & 482601 & 265620 \\
51 & 480446 & 268525 \\
52 & 480387 & 268972 \\
53 & 476405 & 270111 \\
54 & 474664 & 272324 \\
55 & 487988 & 249589 \\
56 & 490101 & 248802 \\
57 & 497937 & 256374 \\
58 & 500712 & 254628 \\
59 & 506331 & 247309 \\
60 & 487841 & 246978 \\
61 & 474857 & 269062 \\
62 & 471020 & 275806 \\
63 & 498032 & 251486 \\
64 & 484731 & 250549 \\
65 & 478855 & 278342 \\
66 & 483763 & 275214 \\
67 & 485602 & 277156 \\
68 & 493343 & 275074 \\
69 & 489744 & 273151 \\
70 & 493096 & 248367 \\
71 & 488882 & 263340 \\
72 & 463857 & 228842 \\
& 467558 & 229901 \\
\hline
\end{tabular}

